\title{
Use Of Train-The-Trainer Sensorimotor Group Experience (TTSMGE) To Promote Functional Motor Skill Development In An Urban US Preschool Environment
}

\author{
Genevieve Pinto Zipp PT, EdD, Seton Hall University, USA
}

Valerie Olson PT, PhD, Seton Hall University, USA

\begin{abstract}
As the demand for services from therapists in the educational environment continues to grow, both physical and occupational therapists seek innovative and effective ways to meet the identified needs of the child and school environment. Train-the-trainer model of service delivery can be used to meet the needs of both the therapist and the preschool educator in aligning the academic curriculum with age appropriate sensory motor activities. The purpose of this paper is to discuss the results obtained from a pilot survey given to school personnel in an urban preschool setting who participated in a Train-the -trainer model of service delivery.
\end{abstract}

Keywords: Train-the-trainer, Sensorimotor group, teaching strategy

\section{INTRODUCTION}

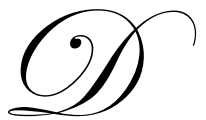

uring the preschool years, children experiment with motor tasks as a way of learning about themselves and their environments. In the educational environment, when working with the young preschool child teachers design educationally relevant learning experiences to advance cognitive, sensory and motor develop. Shasby and Schneck (2005) suggest that the engagement in sensorimotor themed activities promotes the development of academic and sensorimotor skills in all children. Sensorimotor themed activities are based upon the sensory integration frame of reference, coined by Jean Ayers in the 1960's, which uses age appropriate activities to develop sensory, perceptual, and motor skills.

According to Parham and Mailloux (2005), the preschool years are a period in child development where sensorimotor integration rapidly develops as the child interacts with his environment and peers while simultaneously engaging in fine and gross motor skills. During the preschool and kindergarten years, children between the ages of 4-6 years old are drawing, writing their name, tying shoes, skipping, expanding their vocabulary to over 10, 000 words, and interacting with peers in role playing activities, etc. Case-Smith (2005) further notes that children at this age begin to anticipate actions, and thus develop the ability to project and sequence events.

While most children can effectively integrate sensorimotor experiences and meet the challenges of their educational environment, others struggle with the everyday functional tasks. When the child's inability to integrate the sensory information in order to execute a motor response, hinders performance in the school they frequently are referred for further evaluation by health care professionals, such as a physical therapist (PT), occupational therapist (OT), or speech language pathologist (SPL). When evaluating children in the school environment, therapists use an educational frame of reference to determine the child's service needs. Therefore, if a child is unable to function in their educational environment and the therapists (based upon their clinical knowledge) believe that therapy can foster the child's ability to function effectively in the education environment, educationally based therapy services are recommended. 
Therapists working within the school environment possess not only an in-depth knowledge of their profession, but also of the educational system and the laws and regulations that guide educational based service. IDEA Part B, the legislation which guides therapy practice in the school mandates that therapy (PT, OT, SLP) are related services for children with disabilities between the ages of 3 and 21 years of age. The legislation requires that the educational relevant services be provided in the students' least restrictive environments. However, what is meant by the least restrictive environment is unclear to many clinicians and school districts. To date, there is some data to suggest that therapy sessions which incorporate some form of in-class intervention is most beneficial in promoting sensorimotor skill development (Case-Smith and Cable, 1996; Rea, Mclauhlin and Walther 2002). However, the problem exists as to how each clinician and school district defines in-class service provision. Regardless of the type of therapeutic intervention provided, collaboration between the therapist and the teacher is paramount to the success of the child's development. Skill development promotes through repetitive task performance and leads to improved retention and transfer of skills learned during therapy (Shasby and Schneck, 2005).

Barnes and Turner (2001) researched the collaborative practices between occupational therapists and teachers, and the teachers' perceptions of the service benefit. The findings indicated that as the collaboration between the two professionals increased so did the teachers perceptions about the positive contribution of the services. However, there was no structure to the collaborations as an informal type of collaboration was used. Based upon this limitation, the authors suggest the need to investigate the effects of a more structured approach to collaboration such as the sensorimotor group experience. Figure 1 depicts the tenants associated with the sensorimotor group experience. The tenants of this approach center around the collaborative efforts of the teachers, therapists, and teacher's aides with the children, who are actively engaging in sensorimotor tasks that have been designed to meet the needs of the children. Using the sensorimotor group as a vehicle to formalize collaborations may provide more consistent opportunities for the achievement of educationally relevant skills needed by struggling students.

Figure 1. Schematic representation of the tenants associated with the sensorimotor group experience.

\section{Sensorimotor Groups}

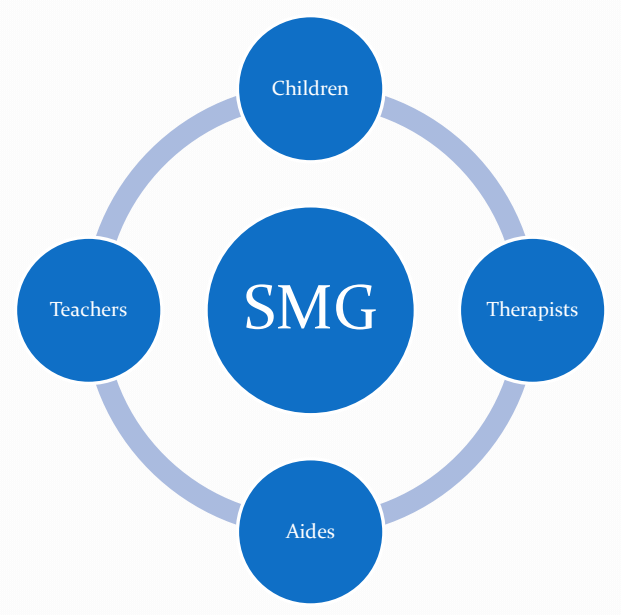

As the demand for services from both physical and occupational therapists in the educational environment continues to grow, therapists must seek innovative and effective ways to meet the identified needs of the child and school environment. Therapists in the educational environment must ensure that their efforts are carried over into the 
student's classroom environment by the educational staff in attempt to promote true skill learning and transfer of skills as a natural part of the daily routine. In many arenas, the therapist is called upon as a consultant for the school personnel. To assist the therapist in meeting this challenge, the role of the preschool educator has expanded. The role includes not only organizing, prioritizing, and planning an educational curriculum, but also to ensure that the academic curriculum is complimented with age appropriate sensorimotor activates to enrich motor development and to promote student academic knowledge. Based upon their educational background, preschool educators are equipped with a general understanding of sensorimotor development; however, often they do not possess the awareness of how to implement actual activities to promote and advance motor skill learning. The physical and occupational therapist possesses advanced knowledge of sensorimotor development and activities to foster this development.

Coupling the sensorimotor group experience with a Train-the-trainer model of teaching and learning may be an effective medium to meet the continuing expanding need to provide services to children in the school environment for the development of motor skills. Traditionally in the field of medicine, an apprentice model of training has been used to teach health care students. Using the primary definition of teaching which is "to show" health care educators have embraced the "train the trainee" model of learning. In the train the trainee model of learning, the trainee learns the skill set via observing, assisting, imitating and finally performing the skill while being supervised. However, the trainers must be effective in modeling the skill set themselves dependent upon the learners (trainees) learning style. Train-the-trainer model of service delivery can be used to meet the needs of both the therapist and the preschool educator in aligning the academic curriculum with age appropriate sensorimotor activities. In this model, the experts (movement scientists/therapist) train individuals (school personnel/teacher) who will carry out the daily activities. For example, in the educational environment, therapists are the experts in the area of sensorimotor development, who, in turn, train the trainers, the teacher and aides.

Evidence-based practice in TTT has been effective as a cognitive and psychomotor training method. The TTT approach has been successfully used in training methods for physicians, nurses, and other health care providers in areas such as chronic fatigue, Alzheimer's disease, STD/HIV prevention, alcohol abuse, tobacco cessation, and social services (Brimmer et al., 2008), as well as for task-specific skills in medical surgery (Murphy et al., 2008). However, no research has addressed the use TTT sensorimotor groups as a way of further developing preschool teachers knowledge base. Typically, instruction methods used to educate teachers consists of conferences and workshops. The didactic presentation of material is frequently advocated, in contrast to the inclusion of experiential, interactive methods, such as TTT, which has demonstrated the ability to change behavior (Masmanian \& Davis, 2002).

The TTT instruction involves a core trainer (expert) who provides instruction or workshops for participants (teachers) to promote increase in knowledge, self-efficacy, and management skills, with the primary goal of conducting secondary presentations to a designated group (Brimmer et al., 2008). The TTT incorporates training based on principles of cognitive learning where the learner develops an explicit mental template thought rehearsal of steps before physically completing the skills. In building skills above and beyond the traditional approach of learning, the articulation of the factual, conceptual, and strategic knowledge related to each step of the procedure promotes improved skills acquisition (Murphy et al., 2008). It is believed that by verbalizing each step of the procedure, the trainer becomes consciously aware of the steps usually performed subconsciously by the expert, bringing him more onto the level of the trainee. Thus, moving from the phenomena of "see one, do one, teach one" to "see one, describe one, do one."(1)

Clearly, there are many questions that can be investigated to help support the use of the Sensorimotor Group Train-the-trainer model in the educational environment. In this pilot study, it is our aim to assess the perceptions of trainees with regard to the benefit of the Train-the-trainer sensorimotor group experience in promoting trainee motivation, engagement, and self confidence. We believe it is important to first understand the trainee's perception as their perception may positively or negatively affect instruction and impact the effectiveness of the sensorimotor group experience and ultimately the sensorimotor development of the students in the group. We anticipate that this study will be the first in a line of work that will enable us to support the use of the TTT model of learning for the development of teacher instructed sensorimotor groups as teacher instructed sensorimotor groups can reach more children throughout the country. 


\section{METHODS}

Subjects: Six preschool teachers volunteered to participate as trainees. The setting was an urban preschool located in Nothern New Jersey, where the preschool students were socio-economically disadvantaged

Procedure: Weekly 30 minute Train the Trainer sensorimotor groups were provided for 5 months to six preschool classes consisting of 12-18 students per class by two trainers. Both trainers were experienced pediatric physical therapists with expertise in the use of sensorimotor groups and educational relevant school based services for over 20 years each. The two trainers provided the weekly TTT sensorimotor group experience along with the six preschool teachers (trainees) as a way of modeling what a group should encompass.

At the end of the 5 month period, a post sensorimotor group survey was left in each participating teachers mailbox with a self addressed return mailing envelop to the sensorimotor group leader (PI). The survey did not request any identifying information nor did the return addressed envelope, as both the mailing and return address were the PI's work address. There survey addressed teacher perceptions on the following: sensorimotor group ability to develop the child's overall abilities and the teacher's ability to support this development through sensorimotor activities. The authors sought and received IRB approval retrospectively for this pilot project.

\section{RESULTS}

Overall, the survey data from this pilot study on 6 trainees supports that the Train -the-trainer model of service delivery was positively received by the trainers.

Specifically noting that,

- $\quad$ TTT sensorimotor group model fostered the preschoolers' development of group dynamic skills

- $\quad$ TTT sensorimotor group activities should be modified based upon needs of preschoolers in group

- $\quad$ TTT sensorimotor group model fostered the preschoolers' development of motor, cognitive, language and social skills

- $\quad$ Participation in TTT sensorimotor group fostered the teachers ability to teach preschoolers' in the area of motor, cognitive, language and social skills

- $\quad$ The role of the leader of the sensorimotor group is to lead, demonstrate, challenge and support

- The use of every-day activities helps students to carryover their skills into other environments outside of their school

- $\quad$ Sensorimotor group experiences promote interactive exchange between all group members

- $\quad$ For preschoolers and teachers the continued use of sensorimotor groups in the preschool environment would be a positive experience for all participants

Table 1-10 demonstrate \% agreement using a 5-point Likert scale of trainee's perceptions on several questions regarding the use of the TTT sensorimotor group experience. 
Table 1: Teacher Perceptions

SM Group Survey

\begin{tabular}{llllll}
\hline & \multicolumn{1}{c}{$\begin{array}{l}\text { Strongly } \\
\text { Agree }\end{array}$} & Agree & Unsure & Disagree & $\begin{array}{c}\text { Strongly } \\
\text { Disagree }\end{array}$ \\
\hline SM group model fostered the preschoolers' development of: & \\
\hline $\begin{array}{l}\text { Group } \\
\text { dynamics \& } \\
\text { turn taking }\end{array}$ & $\begin{array}{l}100 \% \\
(\mathrm{n}=6)\end{array}$ & $\begin{array}{l}0 \% \\
(\mathrm{n}=0)\end{array}$ & $\begin{array}{l}0 \% \\
(\mathrm{n}=0)\end{array}$ & $\begin{array}{l}0 \% \\
(\mathrm{n}=0)\end{array}$ & $\begin{array}{l}0 \% \\
(\mathrm{n}=0)\end{array}$ \\
\hline $\begin{array}{l}\text { Listening } \\
\text { skills \& } \\
\text { following } \\
\text { directions }\end{array}$ & $\begin{array}{l}100 \% \\
(\mathrm{n}=6)\end{array}$ & $\begin{array}{c}0 \% \\
(\mathrm{n}=0)\end{array}$ & $\begin{array}{c}0 \% \\
(\mathrm{n}=0)\end{array}$ & $\begin{array}{l}0 \% \\
(\mathrm{n}=0)\end{array}$ & $\begin{array}{l}0 \% \\
(\mathrm{n}=0)\end{array}$ \\
\hline
\end{tabular}

Table 2: Teacher Perceptions

SM Group Survey

\begin{tabular}{|c|c|c|c|c|c|}
\hline & $\begin{array}{l}\text { Strongly } \\
\text { Agree }\end{array}$ & Agree & Unsure & Disagree & $\begin{array}{l}\text { Strongly } \\
\text { Disagree }\end{array}$ \\
\hline $\begin{array}{l}\text { SM develop- } \\
\text { ment is most } \\
\text { effective in } \\
\text { one-on-one }\end{array}$ & $\begin{array}{l}100 \% \\
(n=6)\end{array}$ & $\begin{array}{c}0 \% \\
(n=0)\end{array}$ & $\begin{array}{c}0 \% \\
(n=0)\end{array}$ & $\begin{array}{c}0 \% \\
(n=0)\end{array}$ & $\begin{array}{l}0 \% \\
(n=0)\end{array}$ \\
\hline $\begin{array}{l}\text { Promotion of } \\
\text { SM skills is } \\
\text { essential in } \\
\text { development of } \\
\text { preschooler }\end{array}$ & $\begin{array}{c}0 \% \\
(n=0)\end{array}$ & $\begin{array}{l}33.3 \% \\
(n=2)\end{array}$ & $\begin{array}{l}16.6 \% \\
(n=1)\end{array}$ & $\begin{array}{l}16.6 \% \\
(n=1)\end{array}$ & $\begin{array}{l}33.3 \% \\
(n=2)\end{array}$ \\
\hline $\begin{array}{l}\text { SM develop- } \\
\text { ment is most } \\
\text { effective in } \\
\text { groups }\end{array}$ & $\begin{array}{l}16.6 \% \\
(n=1)\end{array}$ & $\begin{array}{l}66.6 \% \\
(n=4)\end{array}$ & $\begin{array}{c}0 \% \\
(n=0)\end{array}$ & $\begin{array}{l}16.6 \% \\
(n=1)\end{array}$ & $\begin{array}{l}0 \% \\
(n=0)\end{array}$ \\
\hline
\end{tabular}


Table 3: Teacher Perceptions

SM Group Survey

\begin{tabular}{|c|c|c|c|c|c|}
\hline & $\begin{array}{l}\text { Strongly } \\
\text { Agree }\end{array}$ & Agree & Unsure & Disagree & $\begin{array}{l}\text { Strongly } \\
\text { Disagree }\end{array}$ \\
\hline $\begin{array}{l}\text { SM group } \\
\text { activities } \\
\text { should be } \\
\text { modified based } \\
\text { upon needs of } \\
\text { preschoolers in } \\
\text { group }\end{array}$ & $\begin{array}{l}100 \% \\
(n=6)\end{array}$ & $\begin{array}{l}0 \% \\
(n=0)\end{array}$ & $\begin{array}{l}0 \% \\
(n=0)\end{array}$ & $\begin{array}{l}0 \% \\
(n=0)\end{array}$ & $\begin{array}{l}0 \% \\
(n=0)\end{array}$ \\
\hline $\begin{array}{l}\text { Leader of SM is } \\
\text { most effective } \\
\text { when he/she is } \\
\text { same gender of } \\
\text { preschooler }\end{array}$ & $\begin{array}{l}16.6 \% \\
(n=1)\end{array}$ & $\begin{array}{l}33.3 \% \\
(n=2)\end{array}$ & $\begin{array}{c}0 \% \\
(n=0)\end{array}$ & $\begin{array}{l}0 \% \\
(n=0)\end{array}$ & $\begin{array}{l}50 \% \\
(n=3)\end{array}$ \\
\hline
\end{tabular}

Table 4: Teachers Perceptions

Sensory Motor (SM) Group Survey

\begin{tabular}{lllll}
\hline $\begin{array}{l}\text { Strongly } \\
\text { Agree }\end{array}$ & Agree & Unsure & Disagree & $\begin{array}{l}\text { Strongly } \\
\text { Disagree }\end{array}$
\end{tabular}

SM group model fostered the preschoolers' development of:

\begin{tabular}{llllll}
\hline Motor Skills & $\begin{array}{l}100 \% \\
(\mathrm{n}=6)\end{array}$ & $\begin{array}{c}0 \% \\
(\mathrm{n}=0)\end{array}$ & $\begin{array}{c}0 \% \\
(\mathrm{n}=0)\end{array}$ & $\begin{array}{c}0 \% \\
(\mathrm{n}=0)\end{array}$ & $\begin{array}{l}0 \% \\
(\mathrm{n}=0)\end{array}$ \\
\hline $\begin{array}{l}\text { Cognitive } \\
\text { Skills }\end{array}$ & $\begin{array}{l}83.3 \% \\
(\mathrm{n}=5)\end{array}$ & $\begin{array}{c}16.6 \% \\
(\mathrm{n}=1)\end{array}$ & $\begin{array}{c}0 \% \\
(\mathrm{n}=0)\end{array}$ & $\begin{array}{c}0 \% \\
(\mathrm{n}=0)\end{array}$ & $\begin{array}{l}0 \% \\
(\mathrm{n}=0)\end{array}$ \\
\hline $\begin{array}{l}\text { Language } \\
\text { Skills }\end{array}$ & $\begin{array}{l}66.6 \% \\
(\mathrm{n}=6)\end{array}$ & $\begin{array}{c}33.3 \% \\
(\mathrm{n}=2)\end{array}$ & $\begin{array}{c}0 \% \\
(\mathrm{n}=0)\end{array}$ & $\begin{array}{c}0 \% \\
(\mathrm{n}=0)\end{array}$ & $\begin{array}{l}0 \% \\
(\mathrm{n}=0)\end{array}$ \\
\hline $\begin{array}{l}\text { Socialization } \\
\text { Skills }\end{array}$ & $\begin{array}{l}100 \% \\
(\mathrm{n}=4)\end{array}$ & $\begin{array}{l}0 \% \\
(\mathrm{n}=2)\end{array}$ & $\begin{array}{c}0 \% \\
(\mathrm{n}=0)\end{array}$ & $\begin{array}{c}0 \% \\
(\mathrm{n}=0)\end{array}$ & $\begin{array}{l}0 \% \\
(\mathrm{n}=0)\end{array}$ \\
& & & & \\
\hline
\end{tabular}


Table 5: Teacher Perceptions

SM Group Survey

\begin{tabular}{lllll}
\hline $\begin{array}{l}\text { Strongly } \\
\text { Agree }\end{array}$ & Agree & Unsure & Disagree & $\begin{array}{l}\text { Strongly } \\
\text { Disagree }\end{array}$ \\
\hline
\end{tabular}

When working with preschooler, role of leader of SM group is to:

\begin{tabular}{llllll}
\hline Lead & $\begin{array}{l}83.3 \% \\
(n=5)\end{array}$ & $\begin{array}{c}16.6 \% \\
(n=1)\end{array}$ & $\begin{array}{c}0 \% \\
(n=0)\end{array}$ & $\begin{array}{c}0 \% \\
(n=0)\end{array}$ & $\begin{array}{l}0 \% \\
(n=0)\end{array}$ \\
\hline Demonstrate & $\begin{array}{l}83.3 \% \\
(n=5)\end{array}$ & $\begin{array}{c}16.6 \% \\
(n=1)\end{array}$ & $\begin{array}{c}0 \% \\
(n=0)\end{array}$ & $\begin{array}{c}0 \% \\
(n=0)\end{array}$ & $\begin{array}{l}0 \% \\
(n=0)\end{array}$ \\
\hline Challenge & $\begin{array}{l}66.6 \% \\
(n=6)\end{array}$ & $\begin{array}{c}33.3 \% \\
(n=2)\end{array}$ & $\begin{array}{c}0 \% \\
(n=0)\end{array}$ & $\begin{array}{c}0 \% \\
(n=0)\end{array}$ & $\begin{array}{l}0 \% \\
(n=0)\end{array}$ \\
\hline Support & $\begin{array}{l}100 \% \\
(n=4)\end{array}$ & $\begin{array}{c}0 \% \\
(n=2)\end{array}$ & $\begin{array}{c}0 \% \\
(n=0)\end{array}$ & $\begin{array}{c}0 \% \\
(n=0)\end{array}$ & $\begin{array}{l}0 \% \\
(n=0)\end{array}$ \\
\hline
\end{tabular}

Table 6: Teacher Perceptions

SM Group Survey

\begin{tabular}{|c|c|c|c|c|c|}
\hline & $\begin{array}{l}\text { Strongly } \\
\text { Agree }\end{array}$ & Agree & Unsure & Disagree & $\begin{array}{l}\text { Strongly } \\
\text { Disagree }\end{array}$ \\
\hline $\begin{array}{l}\text { Using every- } \\
\text { day activi- } \\
\text { ties help } \\
\text { student } \\
\text { carryover in } \\
\text { other envi- } \\
\text { ronments }\end{array}$ & $\begin{array}{l}100 \% \\
(n=6)\end{array}$ & $\begin{array}{c}0 \% \\
(n=0)\end{array}$ & $\begin{array}{l}0 \% \\
(n=0)\end{array}$ & $\begin{array}{l}0 \% \\
(n=0)\end{array}$ & $\begin{array}{l}0 \% \\
(n=0)\end{array}$ \\
\hline $\begin{array}{l}\text { Using SM } \\
\text { activities } \\
\text { expanded } \\
\text { due to my } \\
\text { participation }\end{array}$ & $\begin{array}{l}40 \% \\
(n=2)\end{array}$ & $\begin{array}{c}60 \% \\
(n=3)\end{array}$ & $\begin{array}{l}0 \% \\
(n=0)\end{array}$ & $\begin{array}{l}0 \% \\
(n=0)\end{array}$ & $\begin{array}{l}0 \% \\
(n=0)\end{array}$ \\
\hline $\begin{array}{l}\text { Team envi- } \\
\text { ronment of } \\
\text { SM group is } \\
\text { helpful }\end{array}$ & $\begin{array}{l}100 \% \\
(n=6)\end{array}$ & $\begin{array}{c}0 \% \\
(n=0)\end{array}$ & $\begin{array}{l}0 \% \\
(n=0)\end{array}$ & $\begin{array}{l}0 \% \\
(n=0)\end{array}$ & $\begin{array}{l}0 \% \\
(n=0)\end{array}$ \\
\hline
\end{tabular}


Table 7: Teacher Perceptions

SM Group Survey

\begin{tabular}{llccc}
\hline $\begin{array}{l}\text { Strongly } \\
\text { Agree }\end{array}$ & Agree & Unsure & Disagree & $\begin{array}{c}\text { Strongly } \\
\text { Disagree }\end{array}$ \\
\hline
\end{tabular}

The SM group experience promoted:

\begin{tabular}{|c|c|c|c|c|c|}
\hline $\begin{array}{l}\text { Interactive } \\
\text { exchange of } \\
\text { ideas b/w } \\
\text { teacher \& } \\
\text { group leader }\end{array}$ & $\begin{array}{l}83.3 \% \\
(n=5)\end{array}$ & $\begin{array}{l}16.6 \% \\
(n=1)\end{array}$ & $\begin{array}{l}0 \% \\
(n=0)\end{array}$ & $\begin{array}{l}0 \% \\
(n=0)\end{array}$ & $\begin{array}{l}0 \% \\
(n=0)\end{array}$ \\
\hline $\begin{array}{l}\text { Interactive } \\
\text { exchange of } \\
\text { ideas b/w } \\
\text { teacher \& aide }\end{array}$ & $\begin{array}{l}66.3 \% \\
(n=4)\end{array}$ & $\begin{array}{l}16.6 \% \\
(n=1)\end{array}$ & $\begin{array}{l}16.6 \% \\
(n=1)\end{array}$ & $\begin{array}{l}0 \% \\
(n=0)\end{array}$ & $\begin{array}{l}0 \% \\
(n=0)\end{array}$ \\
\hline $\begin{array}{l}\text { Importance of } \\
\text { SM activities } \\
\text { into school } \\
\text { environment }\end{array}$ & $\begin{array}{l}83.3 \% \\
(n=5)\end{array}$ & $\begin{array}{l}16.6 \% \\
(n=1)\end{array}$ & $\begin{array}{l}0 \% \\
(n=0)\end{array}$ & $\begin{array}{l}0 \% \\
(n=0)\end{array}$ & $\begin{array}{l}0 \% \\
(n=0)\end{array}$ \\
\hline
\end{tabular}

Table 8: Teacher Perceptions

SM Group Survey

\begin{tabular}{lllll}
\hline $\begin{array}{l}\text { Strongly } \\
\text { Agree }\end{array}$ & Agree & Unsure & Disagree & $\begin{array}{l}\text { Strongly } \\
\text { Disagree }\end{array}$
\end{tabular}

Using every-day activities help student carryover in other environments:

\begin{tabular}{llllll}
\hline Motivating & $\begin{array}{l}83.3 \% \\
(n=5)\end{array}$ & $\begin{array}{l}16.6 \% \\
(n=1)\end{array}$ & $\begin{array}{c}0 \% \\
(n=0)\end{array}$ & $\begin{array}{c}0 \% \\
(n=0)\end{array}$ & $\begin{array}{l}0 \% \\
(n=0)\end{array}$ \\
\hline Challenging & $\begin{array}{l}83.3 \% \\
(n=5)\end{array}$ & $\begin{array}{c}16.6 \% \\
(n=1)\end{array}$ & $\begin{array}{l}0 \% \\
(n=0)\end{array}$ & $\begin{array}{c}0 \% \\
(n=0)\end{array}$ & $\begin{array}{l}0 \% \\
(n=0)\end{array}$ \\
\hline $\begin{array}{l}\text { Time } \\
\text { Consuming }\end{array}$ & $\begin{array}{l}50 \% \\
(n=3)\end{array}$ & $\begin{array}{c}0 \% \\
(n=0)\end{array}$ & $\begin{array}{c}0 \% \\
(n=0)\end{array}$ & $\begin{array}{l}16.6 \% \\
(n=1)\end{array}$ & $\begin{array}{l}16.6 \% \\
(n=1)\end{array}$ \\
\hline Useful & $\begin{array}{l}83.3 \% \\
(n=5)\end{array}$ & $\begin{array}{c}16.6 \% \\
(n=1)\end{array}$ & $\begin{array}{c}0 \% \\
(n=0)\end{array}$ & $\begin{array}{c}0 \% \\
(n=0)\end{array}$ & $\begin{array}{l}0 \% \\
(n=0)\end{array}$ \\
\hline
\end{tabular}


Table 9: Teacher Perceptions

SM Group Survey

\begin{tabular}{llccc}
\multicolumn{3}{c}{ SM Group Survey } \\
\hline $\begin{array}{l}\text { Strongly } \\
\text { Agree }\end{array}$ & Agree & Unsure & Disagree & $\begin{array}{l}\text { Strongly } \\
\text { Disagree }\end{array}$ \\
\hline
\end{tabular}

My participation in SM group has fostered my ability to teach preschoolers' in the area of:

\begin{tabular}{llllll}
\hline $\begin{array}{l}\text { Motor } \\
\text { Development }\end{array}$ & $\begin{array}{l}83.3 \% \\
(\mathrm{n}=5)\end{array}$ & $\begin{array}{l}16.6 \% \\
(\mathrm{n}=1)\end{array}$ & $\begin{array}{l}0 \% \\
(\mathrm{n}=0)\end{array}$ & $\begin{array}{c}0 \% \\
(\mathrm{n}=0)\end{array}$ & $\begin{array}{l}0 \% \\
(\mathrm{n}=0)\end{array}$ \\
\hline $\begin{array}{l}\text { Cognitive } \\
\text { Development }\end{array}$ & $\begin{array}{l}66.6 \% \\
(\mathrm{n}=4)\end{array}$ & $\begin{array}{l}33.3 \% \\
(\mathrm{n}=2)\end{array}$ & $\begin{array}{c}0 \% \\
(\mathrm{n}=0)\end{array}$ & $\begin{array}{c}0 \% \\
(\mathrm{n}=0)\end{array}$ & $\begin{array}{l}0 \% \\
(\mathrm{n}=0)\end{array}$ \\
\hline $\begin{array}{l}\text { Language } \\
\text { Development }\end{array}$ & $\begin{array}{l}50 \% \\
(\mathrm{n}=3)\end{array}$ & $\begin{array}{l}50 \% \\
(\mathrm{n}=3)\end{array}$ & $\begin{array}{c}0 \% \\
(\mathrm{n}=0)\end{array}$ & $\begin{array}{c}0 \% \\
(\mathrm{n}=0)\end{array}$ & $\begin{array}{l}0 \% \\
(\mathrm{n}=0)\end{array}$ \\
\hline $\begin{array}{l}\text { Socialization } \\
\text { Development }\end{array}$ & $\begin{array}{l}83.3 \% \\
(\mathrm{n}=5)\end{array}$ & $\begin{array}{l}16.6 \% \\
(\mathrm{n}=1)\end{array}$ & $\begin{array}{l}0 \% \\
(\mathrm{n}=0)\end{array}$ & $\begin{array}{c}0 \% \\
(\mathrm{n}=0)\end{array}$ & $\begin{array}{l}0 \% \\
(\mathrm{n}=0)\end{array}$ \\
& & & & & \\
\hline
\end{tabular}

Table 9: Teacher Perceptions

SM Group Survey (Con't)

\begin{tabular}{|c|c|c|c|c|c|}
\hline & $\begin{array}{l}\text { Strongly } \\
\text { Agree }\end{array}$ & Agree & Unsure & Disagree & $\begin{array}{l}\text { Strongly } \\
\text { Disagree }\end{array}$ \\
\hline \multicolumn{6}{|c|}{$\begin{array}{l}\text { My participation in SM group has fostered my ability to teach } \\
\text { preschoolers' in the area of: }\end{array}$} \\
\hline $\begin{array}{l}\text { Group } \\
\text { dynamics \& } \\
\text { turn taking }\end{array}$ & $\begin{array}{l}83.3 \% \\
(n=5)\end{array}$ & $\begin{array}{l}16.6 \% \\
(n=1)\end{array}$ & $\begin{array}{l}0 \% \\
(n=0)\end{array}$ & $\begin{array}{l}0 \% \\
(n=0)\end{array}$ & $\begin{array}{l}0 \% \\
(n=0)\end{array}$ \\
\hline $\begin{array}{l}\text { Listening } \\
\text { skills \& } \\
\text { following } \\
\text { directions }\end{array}$ & $\begin{array}{l}60 \% \\
(n=3)\end{array}$ & $\begin{array}{c}40 \% \\
(n=2)\end{array}$ & $\begin{array}{l}0 \% \\
(n=0)\end{array}$ & $\begin{array}{l}0 \% \\
(n=0)\end{array}$ & $\begin{array}{l}0 \% \\
(n=0)\end{array}$ \\
\hline
\end{tabular}


Table 10: Teacher Perceptions

SM Group Survey

\begin{tabular}{lllll}
\hline $\begin{array}{l}\text { Strongly } \\
\text { Agree }\end{array}$ & Agree & Unsure & Disagree & $\begin{array}{l}\text { Strongly } \\
\text { Disagree }\end{array}$ \\
\hline
\end{tabular}

For preschoolers, continued use of the SM group in the preschool environment would:

\begin{tabular}{llllll}
\hline $\begin{array}{l}\text { Be a positive } \\
\text { experience }\end{array}$ & $\begin{array}{l}100 \% \\
(n=6)\end{array}$ & $\begin{array}{l}0 \% \\
(n=0)\end{array}$ & $\begin{array}{c}0 \% \\
(n=0)\end{array}$ & $\begin{array}{c}0 \% \\
(n=0)\end{array}$ & $\begin{array}{l}0 \% \\
(n=0)\end{array}$ \\
\hline $\begin{array}{l}\text { Help develop } \\
\text { required } \\
\text { preschool skills }\end{array}$ & $\begin{array}{l}100 \% \\
(n=6)\end{array}$ & $\begin{array}{c}0 \% \\
(n=0)\end{array}$ & $\begin{array}{c}0 \% \\
(n=0)\end{array}$ & $\begin{array}{l}0 \% \\
(n=0)\end{array}$ & $\begin{array}{l}0 \% \\
(n=0)\end{array}$ \\
\hline $\begin{array}{l}\text { Help prepare } \\
\text { kindergarten } \\
\text { readiness skills }\end{array}$ & $\begin{array}{l}100 \% \\
(n=5)\end{array}$ & $\begin{array}{c}0 \% \\
(n=0)\end{array}$ & $\begin{array}{c}0 \% \\
(n=0)\end{array}$ & $\begin{array}{l}0 \% \\
(n=0)\end{array}$ & $\begin{array}{l}0 \% \\
(n=0)\end{array}$ \\
\hline $\begin{array}{l}\text { Complement } \\
\text { preschool } \\
\text { curriculum }\end{array}$ & $\begin{array}{l}60 \% \\
(n=3)\end{array}$ & $\begin{array}{l}40 \% \\
(n=2)\end{array}$ & $\begin{array}{c}0 \% \\
(n=0)\end{array}$ & $\begin{array}{l}0 \% \\
(n=0)\end{array}$ & $\begin{array}{l}0 \% \\
(n=0)\end{array}$ \\
\hline
\end{tabular}

Table 10: Teacher Perceptions

SM Group Survey (cont.)

\begin{tabular}{lllcl}
\hline $\begin{array}{l}\text { Strongly } \\
\text { Agree }\end{array}$ & Agree & Unsure & Disagree & $\begin{array}{l}\text { Strongly } \\
\text { Disagree }\end{array}$ \\
\hline
\end{tabular}

For teachers, continued use of the SM group in the preschool environment would:

\begin{tabular}{llllll}
\hline Be a positive experience & $\begin{array}{l}100 \% \\
(\mathrm{n}=5)\end{array}$ & $\begin{array}{l}0 \% \\
(\mathrm{n}=0)\end{array}$ & $\begin{array}{l}0 \% \\
(\mathrm{n}=0)\end{array}$ & $\begin{array}{l}0 \% \\
(\mathrm{n}=0)\end{array}$ & $\begin{array}{l}0 \% \\
(\mathrm{n}=0)\end{array}$ \\
\hline $\begin{array}{l}\text { Help teachers develop } \\
\text { required student } \\
\text { preschool skills }\end{array}$ & $\begin{array}{l}100 \% \\
(\mathrm{n}=5)\end{array}$ & $\begin{array}{l}0 \% \\
(\mathrm{n}=0)\end{array}$ & $\begin{array}{l}0 \% \\
(\mathrm{n}=0)\end{array}$ & $\begin{array}{l}0 \% \\
(\mathrm{n}=0)\end{array}$ & $\begin{array}{l}0 \% \\
(\mathrm{n}=0)\end{array}$ \\
\hline $\begin{array}{l}\text { Help teachers to prepare } \\
\text { kindergarten readiness } \\
\text { skills }\end{array}$ & $\begin{array}{l}100 \% \\
(\mathrm{n}=5)\end{array}$ & $\begin{array}{l}0 \% \\
(\mathrm{n}=0)\end{array}$ & $\begin{array}{l}0 \% \\
(\mathrm{n}=0)\end{array}$ & $\begin{array}{l}0 \% \\
(\mathrm{n}=0)\end{array}$ & $\begin{array}{l}0 \% \\
(\mathrm{n}=0)\end{array}$ \\
\hline $\begin{array}{l}\text { Complement their } \\
\text { current preschool } \\
\text { curriculum }\end{array}$ & $\begin{array}{l}80 \% \\
(\mathrm{n}=4)\end{array}$ & $\begin{array}{l}20 \% \\
(\mathrm{n}=1)\end{array}$ & $\begin{array}{l}0 \% \\
(\mathrm{n}=0)\end{array}$ & $\begin{array}{l}0 \% \\
(\mathrm{n}=0)\end{array}$ & $\begin{array}{l}0 \% \\
(\mathrm{n}=0)\end{array}$ \\
\hline
\end{tabular}




\section{CONCLUSION}

While the data from this pilot study is only from one small urban preschool in the United States, the findings are positive and fuel our desire to ask, "What are the effects of the Train-the-trainer model on a larger scale and does it truly impact positively motor development?" The knowledge gained from this paper on trainee's perceptions towards TTT sensorimotor groups provides educators and therapists with an understanding of the positive impact of using the Train-the-trainer model in developing the sensorimotor skills of preschool children in an urban school.

\section{REFERENCES}

1. Barnes, KJ \& Turner, KD. (2001) Team collaborative practices between teachers and occupationsl therapists. Am J Occup Ther;55:83-89.

2. Brimmer, DJ, McCleary, KK, Lupton, T, Faryna, KM, Hynes, K, Reeves, WC. A train-the-trainer education and promotion program: chronic fatigue syndrome- a diagnostic and management challenge. BMC Med Educ;8:49.

3. Case-Smith, J. (2005). Development of childhood occupations. In J. Case-Smith (5 ${ }^{\text {th }}$ Ed.), Occupational Therapy for children (pp. 88-116). St. Louis: Elsevier.

4. Case-Smith, J. \& Cable, J. (1996). Perceptions of occupational therapist regarding service delivery models in school-based practice. Occu Ther J Res; 16:23-44.

5. Corelli, RL, Felon, CM, Kroon, LA, Prokhorov, AV, Hudmon, KS. (2007). Evaluation of a Train-theTrainer program for tobacco cessation. Am J of Phar Ed:71(6):1-9.

6. Davies, P, Soon, PL, Young, M, Clausen-Yamaki, A. (2004). Validity and reliability of the School Function Assessment in elementary school students with disabilities. Phys Occup Ther in Pedia;24(3):2343.

7. Dunn, W. (2007). Supporting children to participate successfully in everyday life by using sensory processing knowledge. Infants Young Child;20(2):84-101.

8. Dunn, W. (2001). The sensations of everyday life: theoretical, conceptual and pragmatic considerations. Am J Occup Ther, 55, 608-620.

9. Dunn, W., \& Bennett, D. (2002). Patterns of sensory processing in children with attention deficit hyperactivity disorder. Occup Ther J Res, 22, 4-15.

10. Hwang, J, Daview, PL, Taylor, P, Gavin, W. (2002) Validation of School Function Assessment with Elementary School Children. Occup Ther J Res;22(2).

11. Masmanian, PE, Davis, DA. (2002). Continuing medical education and the physician as a learner- guide to the evidence. JAMA;288:1057-1060.

12. Murphy, MA, Neequaye, S, Kreckler, S., Hands, LJ. (2008). Should we Train-the-trainers? Results of a randomized trial. J Am Coll Surg;207:185-190.

13. Parham, LD \& Mailloux, Z. (2005). Sensory integration. In J. Case-Smith (5 ${ }^{\text {th }}$ Ed.), Occupations Therapy for Children (pp. 88-116). St. Louis: Elsevier.

14. Rea, PJ, McLaughlin, VL \& Walther-Thomas, C. (2002). Outcomes for students with disabilities in inclusive and pullout programs. Except Child;68:2002-222.

15. Shasby, S \& Schneck, C. (2005). Use of sensorimotor them groups to enhance developmental skills in preschool and kindergarten children. School System Special Interest Section Quarterly;12(4):1-6. 
NOTES 